\title{
Penicillinase producing Neisseria gonorrhoeae from St Thomas' Hospital 1976-1990 - The first fifteen years
}

\author{
C Warren, I Phillips
}

\begin{abstract}
Objective-To examine the penicillinase producing $N$. gonorrhoeae (PPNG) collected at St Thomas' Hospital from 1976-1990 and, by determination of antibiotic susceptibility pattern and application of three typing methods, examine the prevalence of different gonococcal types. Also to determine whether there is any relationship between antibiotic sensitivity, plasmid profile, auxotype and serovar.
\end{abstract}

Materials and methods-A total of 665 isolates of PPNG from patients attending the Department of Genitourinary Medicine at St Thomas' Hospital were characterised by antibiotic MIC, plasmid profile, auxotyping and serotyping.

Results-Penicillin MICs for $85 \%$ of all isolates were between 0.25 and $32 \mathrm{mg} / 1$. The MIC of tetracycline for $60-80 \%$ of the isolates was $<1 \mathrm{mg} / 1$. A small number of isolates had tetracycline MICs of $32 \mathrm{mg} / 1$ but MICs $>32 \mathrm{mg} / 1$ were not seen. Over $90 \%$ of the isolates were sensitive to the remaining three antibiotics tested, erythromycin, cefuroxime and spectinomycin. The $3 \cdot 2$ or $4 \cdot 4 \mathrm{MDa}$ plasmid with or without the $24.5 \mathrm{MDa}$ conjugal plasmid was seen in all isolates until $1989 / 90$ when a $2.9 \mathrm{MDa}$ beta-lactamase encoding plasmid and the $25 \cdot 2 \mathrm{MDa}$ plasmid mediating tetracycline resistance were also recognised. Ninety-nine percent of all isolates belonged to one of four auxotypes, prototrophic, arginine, proline or proline/arginine requiring. An initial predominance of isolates with the 1A outer membrane protein was reversed in 1982 and $1 B$ has remained predominant. Thirty two different serovars were identified among the 665 isolates, 14 belonged to serogroup $1 \mathrm{~A}$ and 18 to $1 \mathrm{~B}$, and the eight most common accounted for $83.9 \%$ (554) of all isolates. Analysis of the results of combined typing methods showed there was an association between antibiotic resistance, plasmid profile and serogroup. The number of auxotypes and serovars detected in the collection, indicates the possibility that PPNG have been introduced from abroad or outside our local population.

Conclusion-Temporal trends in the distribution of auxotype/serovar classes show that the total population of PPNG isolates is formed by a heterogenous mixture in which certain auxotypel serovar classes appear, disappear and may re-emerge. Others were present throughout in small numbers.

(Genitourin Med 1993;69:201-207)

Introduction

A fundamental change in the pattern of sensitivity of $N$. gonorrhoeae to penicillin occurred in 1976 when cases of infection with penicillinase producing $N$. gonorrhoeae (PPNG) were first reported in the United Kingdom and United States. ${ }^{12}$ It was soon established that the penicillinase, a TEM-1 type beta-lactamase, was plasmid mediated and that two different plasmids were involved. Initially organisms that originated from Africa carried a 3.2 MDa plasmid and those from Asia a 4.4 $\mathrm{MDa}$ plasmid, but these plasmids are now widely distributed. Further beta-lactamaseencoding plasmids have been described, with molecular weights of $2.9,3.05$ and 4.1 $\mathrm{MDa}$. $3-5$

Two further plasmids have been identified in gonococci, a $2.6 \mathrm{MDa}$ cryptic plasmid found in almost all strains examined and a 24.5 MDa conjugal plasmid carried by some strains: the $24.5 \mathrm{MDa}$ plasmid does not control enzyme production but is necessary for mobilisation of the beta-lactamase plasmids during conjugation. A link has also been established between a $25 \cdot 2 \mathrm{MDa}$ plasmid and high level resistance to tetracycline ${ }^{6}$

After the appearance of our first PPNG isolate at St Thomas' Hospital in 1976 the annual number of isolates increased to a peak of 102 in $1982,4.4 \%$ of all gonococcal isolates. The numbers of gonococci isolated at St Thomas', as in the rest of the UK, then decreased dramatically until 1988, after which a slight increase was observed. However, the incidence of PPNG has remained at about 5\% since 1982 .

In order to detect different "types" of PPNG and examine their distribution over the 15 year period since 1976 we have determined the antibiotic susceptibility, plasmid profile, auxotype and serovar of the organisms collected.

\section{Materials and methods}

Bacterial strains

All isolates of PPNG from patients attending the Department of Genitourinary Medicine at St Thomas' Hospital, between November 1976 and December 1990 were collected.
Microbiology,

London, UK 
Organisms isolated after inoculation of clinical samples on VCNT and later VCAT agar (Oxoid Columbia agar CM 331 containing $10 \%$ saponin lysed horse-blood, $3 \mathrm{mg} / 1$ vancomycin, $100000 \mathrm{u} / \mathrm{l}$ colistin, $5 \mathrm{mg} / \mathrm{l}$ trimethoprim and $12500 \mathrm{u} / 1$ nystatin or $1 \mathrm{mg} / 1$ amphotericin B), a variant of the medium that we described in $1972,{ }^{6}$ were identified as $N$. gonorrhoeae on the basis of their colonial and microscopic morphology and a positive oxidase reaction. Until 1987 a positive reaction with the Bacto fluorescent antibody test (Difco) and since 1988 a positive reaction with the Phadebact monoclonal antibody test (Dako) were used to confirm the identification of $N$. gonorrhoeae from genital sites. Isolates from non-genital sites had identification further confirmed by determination of carbohydrate degradation patterns.

From 1976 nitrocefin was used to detect beta-lactamase, according to the method of O'Callaghan et al. ${ }^{7}$ Since the early $1980 \mathrm{~s}$ Intralactam test strips (Mast Laboratories Ltd) have been used.

Strains were stored in nutrient broth containing $8 \%$ glycerol at $-70^{\circ} \mathrm{C}$. A single isolate of each episode of infection was included in the study.

Control organisms including World Health Organisation reference strains and isolates supplied by St Mary's Hospital, Paddington were included in each batch of MIC determinations or typing. In addition, tests were repeated on random isolates to assess reproducibility.

\section{Determination of minimum inhibitory concentrations (MICs)}

MICs were determined by an agar dilution method. The medium used was Oxoid Diagnostic Sensitivity Test Agar (CM 261) supplemented with $10 \%$ saponin-lysed horse blood. Antibiotics tested were: penicillin $0.06-128 \mathrm{mg} / 1$, tetracycline $0.06-2 \mathrm{mg} / 1$, erythromycin $0.001-2 \mathrm{mg} / 1$, cefuroxime $0.001-1 \mathrm{mg} / \mathrm{l}$ and spectinomycin $2-128 \mathrm{mg} / 1$. An overnight culture of each organism was suspended in nutrient broth so that $1 \mu 1$ delivered by multipoint inoculator (Denley) gave an inoculum of $10^{4}$ colony-forming units (cfu). The plates were examined for growth after $18 \mathrm{~h}$ incubation in $7 \% \mathrm{CO}_{2}$ at $36^{\circ} \mathrm{C}$.

MIC determinations were repeated for isolates that were not inhibited by the initial range of dilutions tested. If the antibiotic MIC values were as follows, tetracycline, $\geqslant 2 \mathrm{mg} / \mathrm{l}$, erythromycin $\geqslant 1 \mathrm{mg} / \mathrm{l}$, cefuroxime $\geqslant 1 \mathrm{mg} / \mathrm{l}$ and spectinomycin $\geqslant 32 \mathrm{mg} / \mathrm{l}$ the isolates were considered to be resistant.

\section{Plasmid analysis}

Isolates of PPNG were grown overnight on DST agar supplemented with $10 \%$ saponinlysed horse blood. The plasmids were extracted by the rapid method of Birnboim and Dolys until the end of 1989 , when the method was changed to that of Kado and $\mathrm{Liu}^{9}$ after comparisons of the two techniques had shown that they gave no discrepant results.

\section{Auxotyping}

Auxotypes of the PPNG isolates were identified, by determination of their nutritional requirements for growth with the defined media and method of Copley and Egglestone. ${ }^{10}$ Media lacking proline, arginine, hypoxanthine, uracil, histidine and methionine were used in addition to a complete medium. After incubation at $36^{\circ} \mathrm{C}$ in $7 \% \mathrm{CO}_{2}$ for $18 \mathrm{~h}$ the plates were examined for the presence of growth comparable to that on the complete medium.

\section{Serogrouping}

A panel of twelve monoclonal antibodies raised to the outer membrane protein (OMP) epitopes and supplied by Syva USA Palo Alto, was used for serological classification of the PPNG. ${ }^{11}$ Each antibody was added to a $10 \%$ suspension of staphylococcal Protein A (Calbiochem Cambridge Bioscience), washed in $0.15 \mathrm{M}$ phosphate-buffered saline (PBS), and resuspended to a $1 \%$ suspension. All isolates of PPNG were grown in $7 \% \mathrm{CO}_{2}$ at $36^{\circ} \mathrm{C}$ for $18 \mathrm{~h}$ on GC Base agar (Difco) supplemented with IsoVitaleX. A cloudy suspension was prepared from these cultures in PBS and boiled for 10 minutes to expose the P1 epitopes. One drop of each reagent was mixed with one drop of bacterial suspension on a glass slide and rotated for 2 minutes. The results were read macroscopically and scored by degree of agglutination from very strong $(++++)$ to weak $(+)$. Any reaction of ++ or more was regarded as positive and a serovar was assigned according to the nomenclature of Knapp et al. ${ }^{12}$

Eight isolates of $N$. gonorrhoeae of known serovars were tested as controls against each newly prepared batch of antibodies.

\section{Results \\ Incidence}

The first isolate of PPNG was detected at St Thomas' Hospital in 1976 and was the only one among 1514 gonococcal isolates. The numbers of PPNG rose steadily to around $5 \%$ in 1984, along with an increase in numbers until 1982 of all gonococci isolated (fig 1). Total numbers then declined until 1988 since when a further increase has been observed. During the 15 year period the incidence of PPNG settled between 4\% and 5\% with two peaks of $5.9 \%$ and $6.1 \%$ in 1986 and 1989 respectively (fig 1 ).

The 665 organisms included in this study constitute over $80 \%$ of the PPNG collected between 1976-1990 with 76-100\% viable after storage in any one year.

\section{Minimum inhibitory concentrations}

The minimum inhibitory concentrations (MICs) of penicillin, tetracycline, erythromycin, cefuroxime and spectinomycin for 665 patient isolates are summarised in table 1 .

Eighty-five percent of all isolates tested had penicillin MICs between 0.25 and $32 \mathrm{mg} / 1$, and less than $15 \%$ in any one year had penicillin MIC's $\geqslant 64 \mathrm{mg} / 1$ with three exceptions 


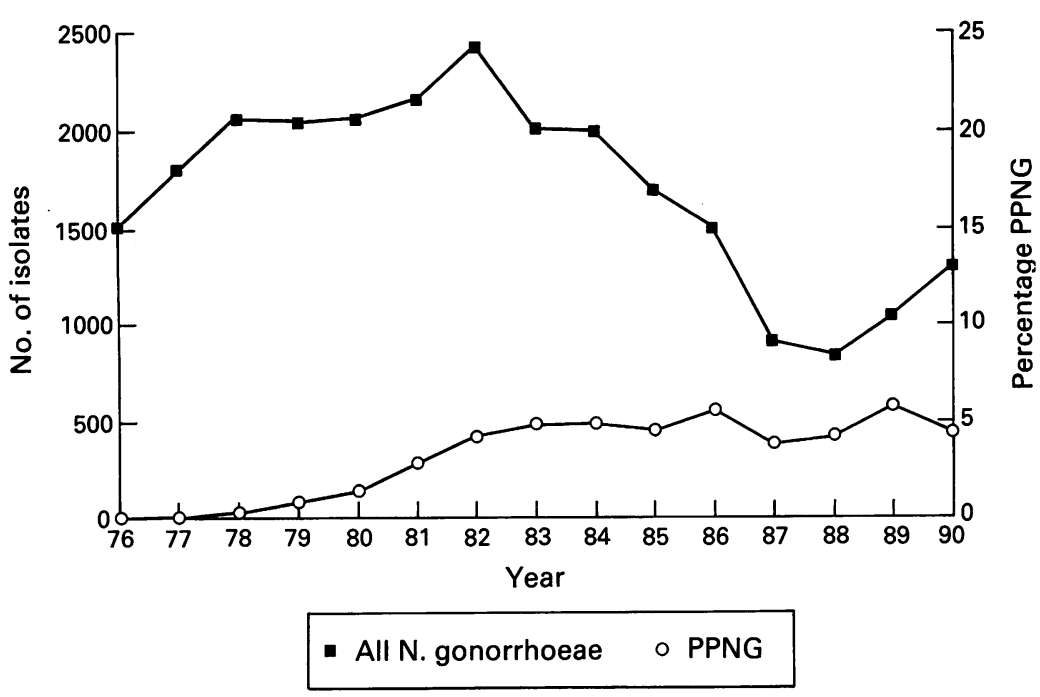

Figure 1 Incidence of PPNG, St Thomas' Hospital 1976-1990.

in 1985,1987 and 1989 when they were 29 , 23 and $26 \%$ respectively.

The MIC of tetracycline for more than $80 \%$ of the isolates was $\leqslant 1 \mathrm{mg} / 1$, until 1982 after which, with the exception of 1986 the percentage dropped to around $60 \%$. Six isolates (one in 1984 and five in 1990) had tetracycline MICs of $32 \mathrm{mg} / 1$ but MICs $>32 \mathrm{mg} / \mathrm{l}$ were not seen.

Concentrations equal to or less than $0.5 \mathrm{mg} / 1$ erythromycin inhibited $89 \%$ of all isolates. The yearly analysis showed the range to be $81-98 \%$ apart from 1989 when it was only $68 \%$. The majority of the remaining isolates were inhibited by $1 \mathrm{mg} / \mathrm{l}$; only five in 1989 were inhibited by $2 \mathrm{mg} / 1$.

Cefuroxime MICs for $99 \%$ of all isolates were $\leqslant 0.5 \mathrm{mg} / 1$. Of the remaining $1 \%$, (four isolates), one was inhibited by $1 \mathrm{mg} / \mathrm{l}$ one by $2 \mathrm{mg} / \mathrm{l}$ and two by $8 \mathrm{mg} / \mathrm{l}$.

Spectinomycin MICs for $96 \%$ of the PPNG tested were $\leqslant 16 \mathrm{mg} / \mathrm{l}$. Of the remaining 26 isolates only four had spectinomycin MICs of $512 \mathrm{mg} / \mathrm{l}$, two in 1982 and two in 1983.
When sensitivity patterns were examined for the agents tested, 222 (33\%) PPNG appeared resistant to antibiotics other than penicillin. Of these 64 showed multiple resistance; 59 were resistant to two other antibiotics: 50 to tetracycline and erythromycin, one to tetracycline and cerfuroxime, five to tetracycline and spectinomycin and three to erythromycin and spectinomycin.

Five isolates were resistant to three additional agents, four to tetracycline, erythromycin and spectinomycin and one to tetracycline, cefuroxime and spectinomycin.

\section{Plasmid analysis}

The plasmid content of 665 isolates of PPNG was determined. The $2.6 \mathrm{MDa}$ cryptic plasmid was found in all but two of the isolates. The first PPNG seen at St Thomas' carried the $3.2 \mathrm{MDa}$ penicillinase-encoding plasmid. In 1978 isolates with both the $4.4 \mathrm{MDa}$ and 24.5 MDa conjugal plasmid appeared but the $3.2 \mathrm{MDa}$ plasmid in conjunction with the conjugal plasmid was not seen until 1981 and isolates with the $4.4 \mathrm{MDa}$ plasmid alone were not seen until 1979 (table 2).

Between 1978-1982 the 3.2 MDa plasmid was detected in $46-65 \%$ of the PPNG but in $1983 / 84$ it was present only in $31 \%$ of the isolates tested. However, from 1985 the percentage increased again with a peak of $86 \%$ in 1988 but levelled out to around $55 \%$ in the last two years. The conjugal plasmid was present only in a small number $(2-11 \%)$ of the PPNG carrying the $3.2 \mathrm{MDa}$ until 1984 but this increased to $32 \%$ by 1988 and to around $50 \%$ in $1989 / 90$ whereas the proportion of PPNG carrying the $4.4 \mathrm{MDa}$ plasmid that also carried the conjugal plasmid was higher when they first appeared, maintaining levels of between 30 and $60 \%$ until 1986 after which the incidence decreased to around $20 \%$.

The period 1989/90 saw the emergence of two new plasmids in the collection, a 2.9 $\mathrm{MDa}$ beta-lactamase encoding plasmid and

Table 1 Patterns of antibiotic susceptibility among PPNG from St Thomas' Hospital 1976-1990

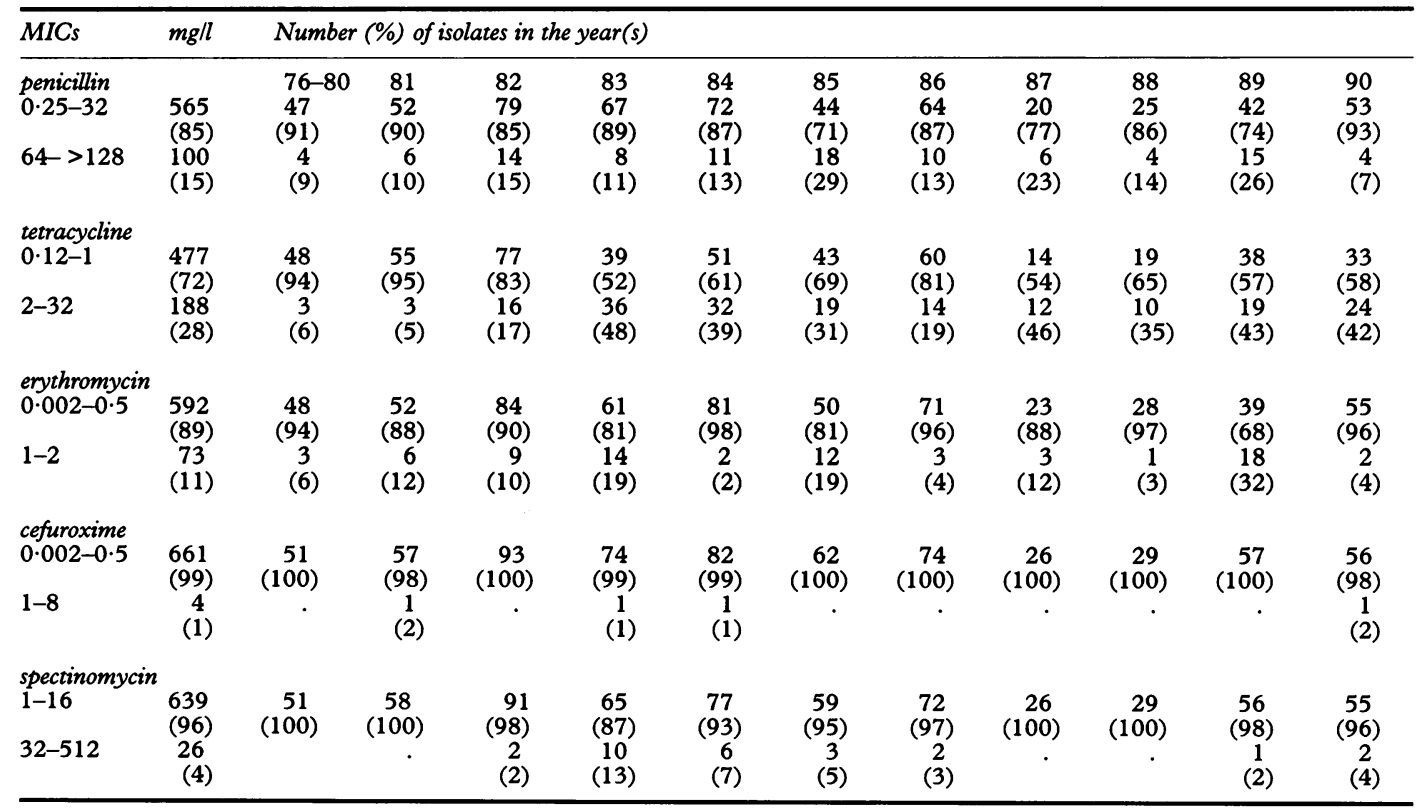


Table 2 Plasmid profiles of PPNG from St Thomas' Hospital 1976-1990

\begin{tabular}{|c|c|c|c|c|c|c|c|c|c|}
\hline \multirow{2}{*}{$\begin{array}{l}\text { Plasmids of } \\
M W(M D a)\end{array}$} & \multirow{2}{*}{$\begin{array}{l}\text { No. of } \\
\text { isolates }\end{array}$} & \multicolumn{8}{|c|}{ Number $(\%)$ of isolates in the year(s) } \\
\hline & & 76 & $77 / 78$ & $79 / 80$ & $81 / 82$ & $83 / 84$ & $85 / 86$ & $87 / 88$ & $89 / 90$ \\
\hline $3 \cdot 2$ & 347 & \multirow{8}{*}{$\begin{array}{c}1 \\
(100)\end{array}$} & \multirow{4}{*}{$\begin{array}{r}4 \\
(67)\end{array}$} & \multirow{4}{*}{$\begin{array}{c}28 \\
(64)\end{array}$} & \multirow{4}{*}{$\begin{array}{c}80 \\
(53) \\
4 \\
(7)\end{array}$} & \multirow{4}{*}{$\begin{array}{c}49 \\
(31) \\
4 \\
(8)\end{array}$} & \multirow{4}{*}{$\begin{array}{c}70 \\
(52) \\
18 \\
(26)\end{array}$} & \multirow{4}{*}{$\begin{array}{c}44 \\
(80) \\
13 \\
(29)\end{array}$} & \multirow{8}{*}{$\begin{array}{c}71 \\
(62)^{\star} \\
37 \\
(52) \dagger \\
8 \\
(11) \\
38 \\
(33)^{\star} \\
10 \\
(26) \dagger \\
5 \\
(5)^{\star} \\
5 \\
(100) \dagger\end{array}$} \\
\hline+24.5 & & & & & & & & & \\
\hline$+24 \cdot 3$ & & & & & & & & & \\
\hline$+25 \cdot 2$ & & & & & & & & & \\
\hline $4 \cdot 4$ & 313 & & $\begin{array}{c}2 \\
(33)\end{array}$ & $\begin{array}{c}16 \\
(36)\end{array}$ & $\begin{array}{c}71 \\
(47)\end{array}$ & $\begin{array}{l}109 \\
(69)\end{array}$ & $\begin{array}{c}66 \\
(48)\end{array}$ & $\begin{array}{c}11 \\
(20)\end{array}$ & \\
\hline$+24 \cdot 5$ & & & $\begin{array}{c}2 \\
(100)\end{array}$ & $\begin{array}{c}7 \\
(44)\end{array}$ & $\begin{array}{c}40 \\
(56)\end{array}$ & $\begin{array}{c}37 \\
(34)\end{array}$ & $\begin{array}{c}28 \\
(42)\end{array}$ & $\begin{array}{c}4 \\
(36)\end{array}$ & \\
\hline $2 \cdot 9$ & 5 & & & & & & & & \\
\hline$+24 \cdot 5$ & & & & & & & & & \\
\hline
\end{tabular}

*Percentages in these rows relate to the total number of isolates for that period

tPercentages in these rows relate to the total number of isolates with the relevant beta-lactamase mediating plasmid.

the $25 \cdot 2 \mathrm{MDa}$ plasmid mediating tetracycline resistance which was found in eight strains carrying the $3 \cdot 2 \mathrm{MDa}$ plasmid. The tetracycline MIC of these strains was 16 or $32 \mathrm{mg} / 1$.

\section{Auxotypes}

Four of the seven auxotypes identified accounted for 659 (99\%) of the 665 PPNG. Of the 659 isolates 247 (37\%) were prototrophic (proto), 83 (13\%) required arginine (arg-), 269 (40\%) required proline (pro-) and $60(9 \%)$ required proline and arginine (pro/arg-) (fig 2).

The distribution of the four main auxotypes is shown in fig 2. Prototrophic and prostrains were predominant until 1982 when they were superceded for a short time by arginine-requiring strains. The incidence of prototrophic strains after 1984 continued to increase, levelling out to around 50\%. Prostrains reached a peak of $63 \%$ in 1984 and then slowly fell to $17 \%$ in 1988 but have shown a rise to around $30 \%$ in the last two years. After the rise to $38 \%$ in 1982 the incidence of arg- strains fell steadily to $<10 \%$ by 1985, none were seen in 1986 and $<20 \%$ up until 1990. Strains that required proline and arginine showed a slight increase to around $20 \%$ in $1987 / 88$ but then declined again to $<10 \%$.

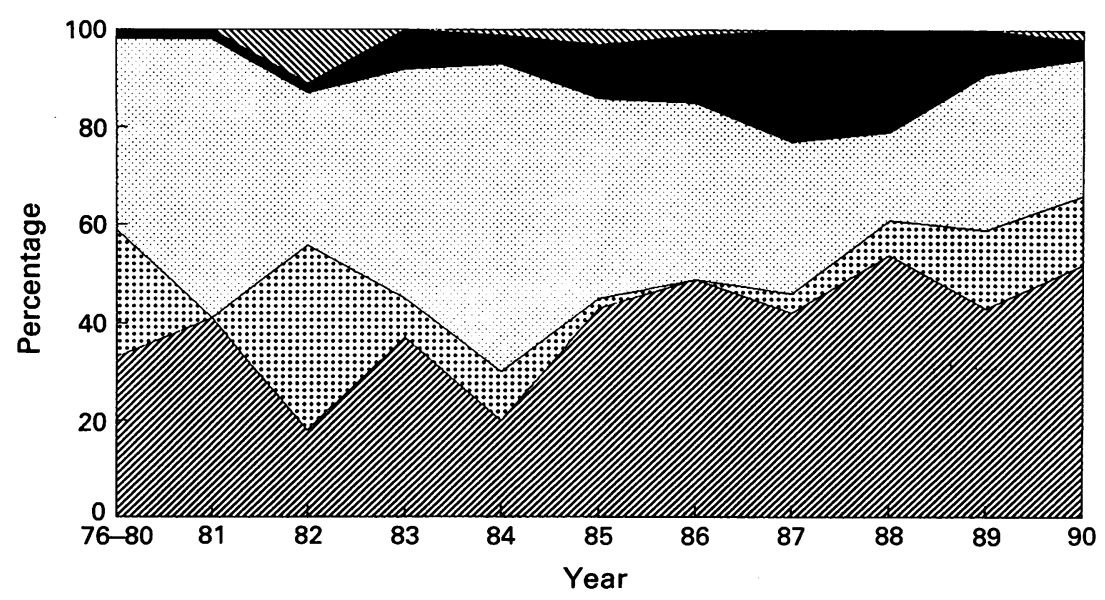

Prototrophic pro/arg- Other

Figure 2 Auxotypes of PPNG, St Thomas' Hospital 1976-1990.
Serogroups and serovars

The incidence of isolates with the $1 \mathrm{~A}$ or $1 \mathrm{~B}$ outer membrane protein is shown in table 3 . An initial predominance of isolates with $1 \mathrm{~A}$ epitopes over those with $1 \mathrm{~B}$ was reversed in 1982 and $1 \mathrm{~B}$ has since remained predominant.

Thirty two serovars were identified amongst the 665 PPNG, fourteen 1A an eighteen 1B (table 3). A small number of is lates could be grouped only as $1 \mathrm{~A}$ or $1 \mathrm{~B}$ as we were unable to assign a serovar with the monoclonal antibodies available.

Eight serovars $1 \mathrm{~A}-1 / 2,1 \mathrm{~A}-4,1 \mathrm{~A}-6,1 \mathrm{~B}-\overline{\overline{\mathrm{b}}}$ $1 \mathrm{~B}-2,1 \mathrm{~B}-3,1 \mathrm{~B}-5 / 7$ and $1 \mathrm{~B}-6$, accounted for $83.9 \%(554)$ of the isolates. Serovars $1 \mathrm{~A}-1$ and $1 \mathrm{~A}-4$ were seen as possible clusters in the earlier years although they have been presem in small numbers each year. Serovar 1-A\% was detected in significant numbers betweet 1981 and 1986. Clusters of the $1 B$ serovars have been noted from the middle to the en of the survey, 1B-1 in 1985-86, 1B-2 in 1984 and $1990,1 \mathrm{~B}-3$ in 1989 and 1990 and $1 \mathrm{~B}-5 \overline{8}$ scattered between 1982 and 1988 (fig 3).

\section{Combined typing methods}

Auxotype-serovar: A total of 72 auxotype/ serovar (A/S) classes was found, nine of which accounted for $53 \%$ of the PPNG tested. The distribution of the four main auxotypes amongst the eight most commol serovars is shown in table 4 these accounted for $83 \%$ of the 665 PPNG. Serovar $1 A-1 / 2$ was mainly arginine-requiring, whereas $1 \mathrm{~A}-\mathrm{E}$, $1 \mathrm{~B}-1,1 \mathrm{~B}-2$ and 1B-6 were predominant proline-requiring and $1 \mathrm{~A}-4$ and $1 \mathrm{~B}-5 / 7$ we prototrophic. Serovar 1B-3 was almost equally divided between arg-, pro- and prototrophic types. Figure 4 shows the distribustion of the eight most common A/S classes. Plasmids-auxotype: The distribution of thie auxotypes between the 660 PPNG with either the 3.2 MDa plasmid (347) or $4 \cdot 4 \mathrm{MDa}$ plas mid (313) showed that whilst prototrophic strains are found mainly in PPNG carrying the $3.2 \mathrm{MDa}$ plasmid, a higher percentage of proline-requiring strains were associated with the 4.4 MDa plasmid.

Plasmid-serogroup and serovar: The 1B OM was detected in $71 \%$ of the PPNG carrying the $4.4 \mathrm{MDa}$ plasmid, but in only $49 \%$ of those with the $3 \cdot 2 \mathrm{MDa}$ plasmid.

Seventy-nine percent of the PPNG that carried the 4.4 MDa plasmid belonged serovars $1 \mathrm{~A}-6,1 \mathrm{~B}-1,1 \mathrm{~B}-2,1 \mathrm{~B}-5 / 7$ or $1 \mathrm{~B}-\mathbb{E}_{\text {, }}$ whereas only $36 \%$ of those with the $3 \cdot 2 \mathrm{MD}_{\theta}$ plasmid belonged to these groups. The pre्)dominant serovar amongst the PPNG wifh the $3 \cdot 2 \mathrm{MDa}$ plasmid was $1 \mathrm{~A}-2(23 \%)$.

Plasmid-A/S class: The A/S classes founel amongst the PPNG carrying the $3.2 \mathrm{MDa}$ plasmid, include proto $1 \mathrm{~A}-4$ which show small cluster in 1981 but has not been se since 1987 , arg-1A-1/2, $26(28 \%)$ of the is lates in 1982 belonged to this A/S class but only three have been detected since 1983 and pro/arg-1B-1 which was only found between 1985-1988. PPNG belonging to the A/S class proto $1 \mathrm{~B}-5 / 7$ were found in almost equal 
Table 3 Serovars of PPNG from St. Thomas' Hospital 1976-1990

\begin{tabular}{|c|c|c|c|c|c|c|c|c|c|c|c|c|}
\hline \multirow[b]{2}{*}{ Serovar } & \multirow{2}{*}{$\begin{array}{l}\text { No }(\%) \\
\text { of isolates }\end{array}$} & \multicolumn{11}{|c|}{ Number of isolation in year(s) } \\
\hline & & $76-80$ & 81 & 82 & 83 & 84 & 85 & 86 & 87 & 88 & 89 & 90 \\
\hline \multirow{14}{*}{$\begin{array}{l}1 \mathrm{~A} 1 / 2 \\
1 \mathrm{~A}-3 \\
1 \mathrm{~A}-4 \\
1 \mathrm{~A}-5 \\
1 \mathrm{~A}-6 \\
1 \mathrm{~A}-8 \\
1 \mathrm{~A}-9 \\
1 \mathrm{~A}-10 \\
1 \mathrm{~A}-13 \\
1 \mathrm{~A}-15 \\
1 \mathrm{~A}-16 \\
1 \mathrm{~A}-18 \\
1 \mathrm{~A}-19 \\
1 \mathrm{~A}-21 \\
1 \mathrm{~A}\end{array}$} & \multirow{14}{*}{$\begin{array}{c}88(13 \cdot 2) \\
6(0 \cdot 9) \\
43(6 \cdot 5) \\
5(0 \cdot 7) \\
99(15 \cdot 1) \\
5(0 \cdot 7) \\
1(0 \cdot 1) \\
1(0 \cdot 1) \\
1(0 \cdot 1) \\
4(0 \cdot 6) \\
1(0 \cdot 1) \\
6(0 \cdot 9) \\
1(0 \cdot 1) \\
4(0.6) \\
2(0.3)\end{array}$} & 20 & \multirow{3}{*}{$\begin{array}{l}2 \\
2 \\
6\end{array}$} & \multirow{3}{*}{$\begin{array}{r}31 \\
2 \\
5\end{array}$} & 9 & \multirow{2}{*}{$\begin{array}{l}4 \\
.\end{array}$} & 6 & 5 & 1 & \multirow[t]{2}{*}{1} & \multirow{2}{*}{$\begin{array}{l}5 \\
1\end{array}$} & \multirow[t]{2}{*}{4} \\
\hline & & 10 & & & 3 & & 2 & $\dot{4}$ & 1 & & & \\
\hline & & & & & & & & & 2 & 2 & & 1 \\
\hline & & 6 & 18 & 10 & 12 & 18 & 7 & 15 & . & 2 & 5 & 6 \\
\hline & & . & 5 & . & . & . & . & . & . & & . & . \\
\hline & & . & . & . & . & . & . & . & . & 1 & . & \\
\hline & & . & . & . & . & & . & . & . & . & . & 1 \\
\hline & & - & & . & . & 1 & . & . & . & & . & . \\
\hline & & - & 1 & $\cdot$ & $\cdot$ & ; & . & . & - & 3 & - & . \\
\hline & & & & & . & 1 & . & . & & . & . & . \\
\hline & & 1 & 1 & 3 & . & . & & . & 1 & · & - & . \\
\hline & & & - & . & . & . & 1 & & . & . & . & \\
\hline & & 1 & . & - & . & . & . & 1 & - & . & - & 2 \\
\hline & & - & . & & . & . & . & 1 & . & . & . & 1 \\
\hline 1B-1 & $76(11 \cdot 5)$ & 2 & 2 & 7 & 7 & 12 & 11 & 12 & 7 & 4 & 8 & 4 \\
\hline 1B-2 & $62(9 \cdot 4)$ & 1 & 1 & & 11 & 20 & 3 & 3 & 3 & 1 & 7 & 12 \\
\hline 1B-3 & $46(7)$ & . & . & 7 & 5 & 3 & 6 & 1 & & 1 & 13 & 10 \\
\hline 1B-4 & $13(2 \cdot 1)$ & & & & 2 & & & 4 & 2 & 1 & 3 & 1 \\
\hline $1 \mathrm{~B}-5 / 7$ & $97(14 \cdot 7)$ & 2 & 4 & 14 & 18 & 14 & 8 & 12 & 7 & 10 & 6 & 2 \\
\hline 1B-6 & $43(6 \cdot 5)$ & 6 & 4 & 5 & 1 & 6 & 6 & 5 & . & . & 3 & 7 \\
\hline 1B-8 & $21(3$ & . & . & 2 & 3 & . & 7 & 3 & . & & 1 & 5 \\
\hline 1B-10 & $1(0 \cdot 1)$ & . & . & . & . & . & . & & . & 1 & . & . \\
\hline 1B-12 & $1(0 \cdot 1)$ & . & . & . & . & . & . & 1 & & . & & . \\
\hline 1B-14 & $1(0 \cdot 1)$ & . & . & . & . & . & . & . & . & - & 1 & . \\
\hline $1 \mathrm{~B}$ & $3(0.4)$ & . & . & . & . & . & & . & . & 2 & 1 & . \\
\hline 1B-18 & $1(0 \cdot 1)$ & & & & & 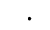 & 1 & . & 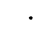 & . & . & \\
\hline 1B-19 & $12(1 \cdot 9)$ & 1 & 2 & 6 & 2 & . & . & & . & . & . & 1 \\
\hline 1B-20 & $2(0 \cdot 3)$ & . & . & & . & . & . & 2 & . & . & . & . \\
\hline 1B-22 & $1(0 \cdot 1)$ & . & . & 1 & . & . & . & . & . & . & & . \\
\hline $1 \mathrm{~B}-23$ & $2(0 \cdot 3)$ & . & . & . & & 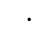 & & . & . & . & 2 & \\
\hline 1B-26 & $3(0 \cdot 4)$ & . & . & . & 1 & . & 1 & . & . & . & . & 1 \\
\hline 1B-28 & $1(0 \cdot 1)$ & . & $\cdot$ & . & 1 & & & & & $\cdot$ & $\cdot$ & . \\
\hline 1B & $12(1 \cdot 9)$ & . & . & . & & 2 & 3 & 5 & 2 & . & . & . \\
\hline Totals & 665 & 51 & 58 & 93 & 75 & 83 & 62 & 74 & 26 & 29 & 57 & 57 \\
\hline 1A & $269(40)$ & 40 & 46 & 50 & 27 & 25 & 16 & 25 & 5 & 9 & 11 & 15 \\
\hline 1B & $396(60)$ & 11 & 12 & 43 & 48 & 58 & 46 & 49 & 21 & 20 & 46 & 42 \\
\hline
\end{tabular}

numbers among gonococci with either the $3 \cdot 2$ $\mathrm{MDa}$ or $4.4 \mathrm{MDa}$ plasmid they appeared between 1983 and 1990 in PPNG with the 3.2 MDa plasmid (table 5).

With the exception of the proto $1 \mathrm{~B}-5 / 7 \mathrm{~A} / \mathrm{S}$ class seen between 1981 and 1986 but not since, a different group of predominant $\mathrm{A} / \mathrm{S}$ classes was found amongst PPNG with the 4.4 MDa plasmid. These include pro-1A-6, with a cluster in 1981 but very few isolates since 1986, pro-1B-2, which didn't appear until 1983 but shows a cluster in 1984 and pro-1B-1 which was present until 1986 with only two isolates seen since (table 5).

Comparison of plasmid profiles among certain A/S classes shows that some types have appeared only over a short period of time,

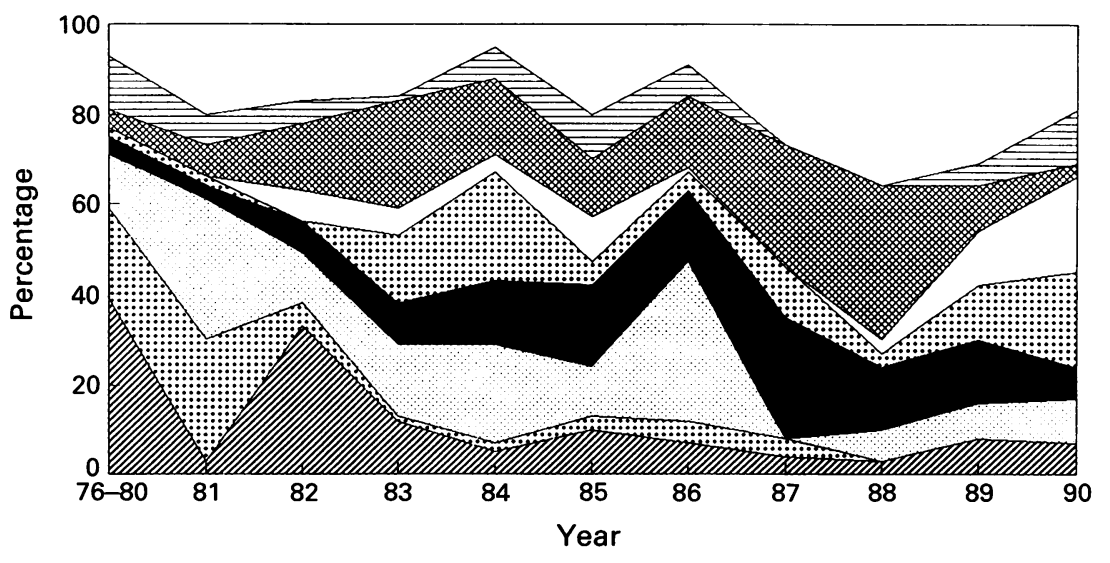

\begin{tabular}{|c|c|c|c|c|c|c|}
\hline שIIS & $1 \mathrm{~A}-1 / 2$ & i & $1 A-4$ & $\square$ & $1 A-6$ & 1B-1 \\
\hline : & 1B-2 & $\square$ & $1 B-3$ & 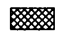 & 1B-5/7 & 1B-6 \\
\hline
\end{tabular}

Figure 3 Serovars of PPNG, St Thomas' Hospital 1976-1990.
Table 4 Auxotype of the eight most common serovars among ppng from St Thomas' Hospital 1976-1990

\begin{tabular}{lllrrr}
\hline & \multirow{2}{*}{$\begin{array}{l}\text { No. (\%) of } \\
\text { isolates }\end{array}$} & \multicolumn{4}{c}{ Number of isolates with auxotype } \\
\cline { 3 - 6 } Serovar & proto & arg & pro $^{-}$ & prolarg \\
\hline $1 \mathrm{~A}-1 / 2$ & $87(13 \cdot 2)$ & 14 & 48 & 22 & 3 \\
$1 \mathrm{~A}-4$ & $42(6 \cdot 5)$ & 35 & & 7 &. \\
$1 \mathrm{~A}-6$ & $97(14 \cdot 6)$ & 30 & 2 & 61 & 4 \\
$1 \mathrm{~B}-1$ & $76(11 \cdot 5)$ & 18 & 3 & 39 & 16 \\
$1 \mathrm{~B}-2$ & $61(9 \cdot 4)$ & 16 & 1 & 39 & 5 \\
$1 \mathrm{~B}-3$ & $46(7 \cdot 0)$ & 13 & 15 & 14 & 4 \\
$1 \mathrm{~B}-5 / 7$ & $97(14 \cdot 7)$ & 47 & 7 & 29 & 14 \\
$1 \mathrm{~B}-6$ & $43(6 \cdot 5)$ & 14 & 1 & 27 & 1 \\
\hline
\end{tabular}

others as possible clusters and some are found in small numbers throughout the fifteen year period (table 6).

MIC-plasmids/serogroup/auxotype: Seventyone percent of the 188 PPNG that had MICs of tetracycline $\geqslant 2 \mathrm{mg} / 1$ carried the $4.4 \mathrm{MDa}$ plasmid and $95 \%$ had the 1B OMP; of the remaining 477 isolates with lower tetracycline MICs $39 \%$ carried the $4.4 \mathrm{MDa}$ plasmid and $45 \%$ belonged to serogroup $1 \mathrm{~B}$. Of the 73 PPNG with erythromycin MICs $\geqslant 1 \mathrm{mg} / 1$ $69 \%$ carried the $4.4 \mathrm{MDa}$ plasmid and $92 \%$ the 1B OMP, $45 \%$ of the 592 PPNG inhibited by less than $1 \mathrm{mg} / 1$ erythromycin carried the $4.4 \mathrm{MDa}$ plasmid and $55 \%$ belonged to the $1 \mathrm{~B}$ serogroup. Between 75 and $90 \%$ of all of these groups of PPNG were either prototrophic or proline-requiring.

Of the sixty four PPNG that showed an increase in MIC to more than one antibiotic, $73 \%$ carried the $4.4 \mathrm{MDa}$ plasmid and $94 \%$ belonged to serogroup $1 \mathrm{~B}, 89 \%$ were almost equally divided between two auxotypes, prototrophic and proline-requiring.

\section{Discussion}

Penicillinase producing $N$. gonorrhoeae was first reported from St Thomas' Hospital in $1976^{1}$ and there were further reports in 1976 from the United Kingdom and the United States. $^{213}$ The plasmid complement of PPNG isolated at St Thomas' Hospital in the ensuing years follows a similar pattern to that observed by other workers. ${ }^{14} 15$ In Liverpool isolates carrying the $4.4 \mathrm{MDa}$ plasmid without the conjugative plasmid were seen earlier in 1978 but the combination of the $3 \cdot 2 \mathrm{MDa}$ plasmid with the conjugative plasmid was not seen until $1982 .{ }^{16} \mathrm{~A}$ change from a predominance of isolates carrying the $3 \cdot 2 \mathrm{MDa}$ plasmid to those carrying the $4.4 \mathrm{MDa}$ plasmid has been reported in Florida 1983-1984 ${ }^{17}$ and in Amsterdam 1982. ${ }^{18}$

The $2.9 \mathrm{MDa}$ beta-lactamase encoding plasmid first described in the Netherlands in $1985^{3}$ did not appear among our isolates until 1989 , always in conjunction with the 24.5 $\mathrm{MDa}$ transfer plasmid. We have not isolated two further beta-lactamase encoding plasmids, 3.05 and 4.1 $\mathrm{MDa}$ described elsewhere. ${ }^{45}$ The $25 \cdot 2 \mathrm{MDa}$ plasmid associated with high-level tetracycline resistance in gonococci was first described in $1986^{19}$ and first appeared in our isolates in 1990, in eight isolates with tetracycline MICs of 16 or $32 \mathrm{mg} / \mathrm{l}$. 


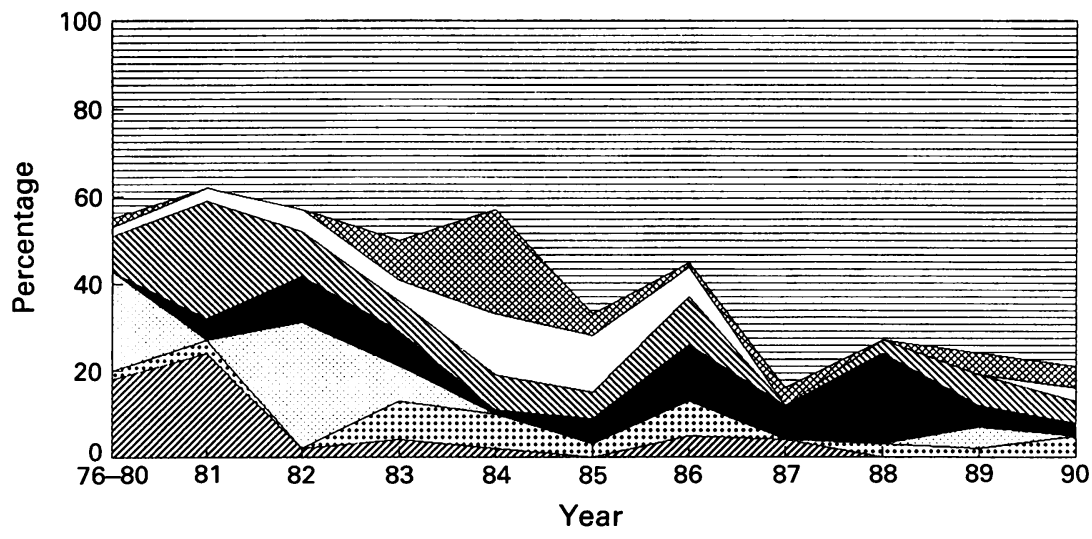

Proto $1 A-4$ Proto $1 A-6 \square$ arg $1 A-1 / 2$ pro $1 A-6$ pro 1B-1 pro 1B-2 Proto $1 B-5 / 7$ All others

Figure 4 Auxo-serovars (A/S classes) of PPNG St Thomas' Hospital 1976-1990.

Table 5 Auxotype/serovar classes of PPNG carrying 3.2 or 4.4 MDa plasmids from St Thomas' Hospital 1976-1990

\begin{tabular}{|c|c|c|c|c|c|c|c|c|c|c|c|c|}
\hline \multirow[b]{2}{*}{$A / S$ class } & \multirow[b]{2}{*}{ Isolates } & \multicolumn{11}{|c|}{ Number of isolates of PPNG in year(s) } \\
\hline & & $76-80$ & 81 & 82 & 83 & 84 & 85 & 86 & 87 & 88 & 89 & 90 \\
\hline $\begin{array}{l}3 \cdot 2 \mathrm{MDa} \\
\text { proto } 1 \mathrm{~B}-5 / 7\end{array}$ & 22 & & & & 1 & & 1 & 7 & 2 & 6 & 3 & 2 \\
\hline $1 \mathrm{~A}-4$ & 33 & 9 & 14 & 2 & 1 & 2 & . & 4 & 1 & & & \\
\hline $1 \mathrm{~A}-6$ & 20 & & 1 & & 7 & 3 & . & 6 & . & 1 & 1 & 1 \\
\hline $\arg ^{-1 A}-1 / 2$ & 47 & 12 & & 26 & 6 & & . & & . & . & 3 & \\
\hline pro $^{-1 A}-1 / 2$ & 16 & 4 & 1 & 2 & 1 & 1 & 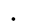 & 3 & - & & . & 4 \\
\hline pro/arg 1B-1 & 16 & . & . & $\cdot$ & . & . & 1 & 6 & 6 & 3 & . & . \\
\hline $\begin{array}{l}4 \cdot 4 \mathrm{MDa} \\
\text { proto } 1 \mathrm{~B}-5 / 7\end{array}$ & 25 & & 3 & 10 & 5 & 1 & 3 & 3 & $\cdot$ & . & & \\
\hline pro- $1 A-6$ & 53 & 4 & 14 & 8 & 5 & 7 & 2 & 7 & . & . & 3 & 3 \\
\hline $1 \mathrm{~B}-1$ & 38 & 1 & 2 & 5 & 4 & 12 & 7 & 5 & 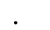 & . & & 2 \\
\hline 1B-2 & 34 & & & . & 7 & 18 & 3 & 1 & 1 & . & 3 & 1 \\
\hline $1 \mathrm{~B}-5 / 7$ & 24 & 2 & 1 & . & 9 & 3 & & 1 & 3 & 4 & 1 & \\
\hline 1B-6 & 24 & 3 & 3 & 4 & . & 4 & 3 & 5 & . & . & 1 & 1 \\
\hline
\end{tabular}

Among PPNG there was a marked increase in MICs for other antibiotics. For tetracycline, with the exception of a peak in 1983 $(48 \%)$ the numbers of isolates with MIC $\geqslant 2 \mathrm{mg} / \mathrm{l}$ was around $30 \%$ until 1986 but since then this has increased to more than $40 \%$. The annual rate of erythromycin resistance (MIC > $1 \mathrm{mg} / \mathrm{l}$ ) has been less than $20 \%$ with the exception of 1989 when it reached $32 \%$. Very few isolates were resistant to cefuroxime (MIC $>1 \mathrm{mg} / \mathrm{l}$ ) and only four iso-

Table 6 PPNG clusters according to A/S class and plasmid profile from St. Thomas' Hospital 1976-1990

\begin{tabular}{|c|c|c|c|c|c|c|c|c|c|c|c|c|}
\hline \multirow[b]{2}{*}{ A/S class } & \multirow[b]{2}{*}{ Isolates } & \multicolumn{11}{|c|}{ Number of isolates of PPNG in year $(\mathrm{s})$} \\
\hline & & $76-80$ & 81 & 82 & 83 & 84 & 85 & 86 & 87 & 88 & 89 & 90 \\
\hline \multirow{4}{*}{$\begin{array}{c}\text { proto } 1 \mathrm{~B}-5 / 7 \\
\text { 3.2MDa } \\
4 \cdot 4 \mathrm{MDa} \\
1 \mathrm{~A}-6 \\
\text { 3.2. } \\
4 \cdot 4 \mathrm{MDa} \\
\end{array}$} & & & & & & & & & & & & \\
\hline & 22 & $\cdot$ & 3 & 10 & 1 & 1 & 1 & 7 & 2 & 6 & 3 & 2 \\
\hline & & & 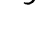 & 10 & & 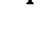 & & & & & & \\
\hline & $\begin{array}{l}20 \\
10\end{array}$ & 1 & 1 & · & 7 & $\begin{array}{l}3 \\
4\end{array}$ & 2 & 6 & : & 1 & 1 & $\frac{1}{2}$ \\
\hline \multirow{2}{*}{$\begin{array}{c}\arg 1 \mathrm{~A}-1 / 2 \\
3 \cdot 2 \mathrm{MDa} \\
4 \cdot 4 \mathrm{MDa}\end{array}$} & & & & & & & & & & & & \\
\hline & $\begin{array}{r}47 \\
1\end{array}$ & 12 & . & $\begin{array}{r}26 \\
1\end{array}$ & 6 & . & . & . & . & . & 3 & . \\
\hline \multirow{2}{*}{$\begin{array}{l}\text { pro- }^{-1 \mathrm{~B}-1} \\
3.2 \mathrm{MDa} \\
4 \cdot 4 \mathrm{MDa}\end{array}$} & & & & & & & & & & & & \\
\hline & 30 & & $?$ & 5 & 4 & 12 & 7 & 5 & · & 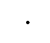 & & 2 \\
\hline \multirow{3}{*}{$\begin{array}{l}\text { pro/arg- } \\
3.2 \mathrm{MDa} \\
4 \cdot 4 \mathrm{MDa}\end{array}$} & & 2 & 2 & 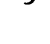 & z & 12 & & 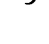 & & & & 2 \\
\hline & 16 & . & & $\cdot$ & . & . & 1 & 6 & 6 & 3 & & . \\
\hline & 0 & & & 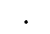 & 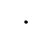 & . & & & & & & \\
\hline
\end{tabular}

lates in 1982-83 showed high level resistance to spectinomycin (MIC $512 \mathrm{mg} / \mathrm{l}$ ). Multiple resistance has been relatively uncommon, many of these isolates belonged to the $1 \mathrm{~B}$ serogroup and carried the $4.4 \mathrm{MDa}$ plasmid.

Four of the seven auxotypes found amongst the PPNG, (proto, arg-, pro- and pro-/arg-) accounted for $99 \%$ of the isolateg, a finding similar to that of Ison and Easmon. ${ }^{20}$ Whilst proto and arg- auxotypess are common amongst all gonococci, we found pro- and pro-/arg- isolates more commondy amongst gonococci with raised antibiotic MICs. A reversal in predominance of proti over pro- strains occurred in 1985 and his continued.

The major outer membrane protein and porin of $N$. gonorrhoeae, Protein 1 (P1) occues as two structural subclasses, P1A and P1B. Any isolate of $N$. gonorrhoeae will usual express only one of these serogroup antigens, but within each subclass there is antigen variation which allows further subdivision into serovars.

A dramatic change in prevalance from is $\Theta$ lates with the $1 \mathrm{~A}$ epitope to those with 1 is was seen in 1982, and remained so until 1990. Clusters of serovars $1 \mathrm{~A}-1 / 2,1 \mathrm{~A}-4$ ant 1A- 6 were seen at the beginning of the survey, whereas after 1982 , there were clusters of 1B-1, 1B-2, 1B-3, 1B-5/7 although $1 \mathrm{~A}-6$, was present in significant numbers until 1986. the thirty two serovars detected, 20 wefe identical to those found by Ison argd Easmon $^{20}$ in the PPNG examined from Sुt Mary's Hospital between 1978-87. The remaining three serovars in the St Mary's stu然 were not seen at St Thomas'. The extra twelve serovars amongst the $S t$ Thomas, PPNG includes 1B-6, one of the eight commonest serovars in the study, indicating possible differences in the geographicid distribution of serovars.

Analysis of the results of combined typing methods shows that there is an association between antibiotic resistance, plasmid profife and serogroup. Of the 64 PPNG resistant to more than one antibiotic, $94 \%$ carried the 4.4 $\mathrm{MDa}$ plasmid and the four PPNG win spectinomycin MICs of $512 \mathrm{mg} / 1$ all carried this plasmid: this was also reported by Ison, Gedney et $a l^{15}$ and Zenilman et al. ${ }^{17} \mathrm{~A}$ higher percentage of these isolates were also prolifie requiring, an observation also made by van Klingeren et al. ${ }^{14}$

Seventy-one percent of PPNG with the 4.44 $\mathrm{MDa}$ plasmid belonged to serogroup iB whereas only $32 \%$ of those with the $3.2 \mathrm{M}$ plasmid belonged to this serogroup, a similar relationship between plasmid type and serogroup to that seen by Ison et al. ${ }^{20}$

Temporal analyses of the distribution $8 f$ the A/S classes show that the total population of PPNG isolates is formed of a heterogeneous mixture, in which certain A/S class appear, disappear and frequently re-emerge. Others were present throughout in small numbers. A study in Florida ${ }^{17}$ describes two A/S classes accounting for $66 \%$ of PPNG isolated in early 1986 indicating an outbreak 
with these two strains. Throughout our study the highest percentage accounted for by any two A/S classes was $48 \%$ demonstrating a more heterogeneous mix of isolates. Our laboratory results therefore suggest that the apparently simple epidemic curve is made up of a large number of introductions of new isolates into our population, some of which spread while others remain confined to small numbers of patients.

1 Phillips I. $\beta$-lactamase-producing, penicillin-resistant gonococcus. Lancet 1976;2:656-7.

2 Ashford WA, Golash RG, Hemming VG. Penicillinaseproducing Neisseria gonorrhoeae. Lancet 1976;2:657-8.

3 van Embden JDA, Dessens-Kroon $\mathbf{M}$, van Klingeren B. A new $\beta$-lactamase plasmid in Neisseria gonorrhoeae. f Antimicrob Chemother 1985;13:247-50.

4 Yeung K-H, Dillon JR, Pauze M, Wallace E. A novel 4.9kilobase plasmid associated with an outbreak of penicilkilobase plasmid associated with an outbreak of penicillinase-producing

5 Gouby A, Bourg G, Ramuz M. Previously undescribed 6.6-kilobase $R$ plasmid in penicillinase-producing Neisseria gonorrhoeae. Antimicrob Agents Chemother 1986; 29:1095-7.

6 Phillips I, Humphrey D, Middleton A, Nicol CS. Diagnosis of gonorrhoeae by culture on selective medium containing vancomycin, colistin, nystatin and trimethoprim (VCNT): a comparison with Gram staining and immunofluorescence. Br $\mathcal{F}$ Venereal Dis 1972; 48:287-92.

7 O'Callaghan CH, Morris A, Kirby SM, Shingler AH. Novel method for detection of beta-lactamases by using a chromogenic cephalosporin substrate. Antimicrob a chromogenic cephalosporin

8 Birnboim HC, Doly J. A rapid alkaline extraction procedure for screening recombinant plasmid DNA. Nucleic
Acid Res 1979;7:1513-23.

9 Kado CI, Liu ST. Rapid procedure for detection and isolation of large and small plasmids. $f$ Bacteriol 1981;145:1365-7.

10 Copley CG, Egglestone SI. Auxotyping of Neisseria gonorrhoeae isolated in the United Kingdom. F Med Microbiol 1983;16:295-302.

11 Tam MR, Buchanan TM, Sandstrom EG, et al. Serological classification of Neisseria gonorrhoeae with monoclonal antibodies. Infect Immun 1982;36:1042-53.

12 Knapp JS, Tam MR, Nowinski RC, Holmes KK, Sandstrom EG. Serological classification of Neisseria gonorrhoeae with use of monoclonal antibodies to gonococcal outer membrane protein 1 . F Infect Dis 1984; coccal ou $150: 44-8$.

13 Percival A, Rowlands J, Corkhill JE, et al. Penicillinaseproducing gonococci in Liverpool. Lancet 1976;2: 1379-82.

14 van Klingeren B, Ansink-Schipper MC, Dessens-Kroon $M$, Verheuvel M. Relationship between auxotype, plasmid pattern and susceptibility to antibiotics in penicillinase-producing Neisseria gonorrhoeae. $\mathcal{F}$ Antimicrob Chemother 1985;16:143-7.

15 Ison CA, Gedney J, Harris JRW, Easmon CSF. Penicillinase producing gonococci: a spent force? Genitourin Med 1986;62:302-7.

16 Arya OP, Rees E, Turner GC, Percival A, et al. Epidemiology of penicillinase-producing Neisseria gonorEhoeae in Liverpool from 1977 to 1982 . Infection rhoeae in Liver

17 Zenilman JM, Whittington WL, Frazier D, et al. Penicillinase-producing Neisseria gonorrhoeae in Dade County, Florida: Phenotypic Characterization of Isolates from 1983, 1984 and 1986. Sex Transm Dis 1988;15:158-63.

18 Ansink-Schipper MC, Bygdeman SM, van Klingeren B, Sandstrom EG. Serovars, auxotypes, and plasmid profiles of PPNG strains with Asian type plasmid isolated in Amsterdam. Genitourin Med 1988;64:152-5.

19 Morse SA, Johnson SR, Biddle JW, Roberts MD. Highlevel tetracycline resistance in Neisseria gonorrhoeae is a level tetracycline resistance in Neisseria gonorrhoeae is a Antimicrob Agents Chemother 1986;30:664-70.

20 Ison CA, Easmon CSF. Changes in penicillinase-producing Neisseria gonorrhoeae in London. $f$ Med Microbiol 1989;30:239-44. 